\title{
1
}

\section{The Housing Sector in Africa: Setting the Scene}

\subsection{Background}

The analysis presented in this book comes at a very critical time for Africa. Several countries are embarking on structural transformation processes and undergoing tremendous economic, demographic, and social change while trying to minimize the negative effects of climate change. After more than a decade of strong economic growth, declines in commodity prices and economic weaknesses in developed and emerging markets are putting downward pressures on Africa's economic growth. Major exporters of oil and minerals, which include some of the most populous countries in the continent, are facing severe budget constraints, inherently undermining growth. Whether this economic slowdown is transitory or long lasting remains to be seen. However, this phenomenon will increase the economic challenges faced by many African cities, including high unemployment rates, large housing deficits, and poor urban infrastructure. If African countries are to spur inclusive growth and reduce poverty, the way in which they respond to their demographic and urban challenges will be crucial. 
This book is an attempt to respond to the urgent need for a critical assessment of Africa's housing market dynamics, opportunities, and challenges, as well as to the role that the main stakeholders-including governments, private sector, NGOs, civil society, and development finance institutions (DFIs) — can play in designing and implementing policies and programs to improve access to affordable housing products for the poor. It highlights the fact that housing construction is a source of inclusive growth, given the labor-intensive nature of the sector. Moreover, in light of the severe housing deficit, which disproportionally affects lowand middle-income households, addressing the continent's housing crisis has the potential to boost economic growth and mitigate income disparities. The extensive backward and forward linkages of housing construction also mean that growth will be broad based.

Although the housing sector varies across countries and regions, the common reality among urban developing markets has been a surge in the demand for housing, effectively driving up housing prices and pushing quality housing out of reach for the majority of those who are in need, especially poor and middle-income households. Simultaneously, slum populations have continued to grow, as social housing cannot keep up with the demand from those in the bottom half of the income distribution. Affordability issues are preventing households from getting their foot on or moving up the housing ladder. Although all these trends are known, much of the literature on housing has been anecdotal. The unique character of this book is related to its comprehensive collection and analysis of housing sector data gathered from across the continent, in order to better tell Africa's housing sector story. A substantial number of factfinding visits and consultations have been carried out in all five regions of the continent to get first-hand data, to collect secondary data, and to meet and discuss with key stakeholders involved in the housing value chain.

The analysis presented in this book also aims to come up with good practices and approaches that have proved successful in other emerging markets that may be adaptable to the circumstances encountered in the African housing market. In so doing, the study draws from experiences, programs, and approaches in developed and emerging countries that have shown success in responding to affordable housing challenges. The 
fact-finding visits also provided a sizeable amount of knowledge about what works and what does not work in different parts of the continent. All in all, the book provides avenues for collaboration, peer learning, and cross-fertilization.

To better frame the discussion in this book, this chapter discusses below a few trends and patterns recently observed in Africa's development that have a bearing on housing market dynamics, with a view to establishing or reemphasizing the importance of the housing market in Africa and why special attention should be devoted to the housing sector.

\subsection{The Roots of Africa's Housing Crisis: Demography and Urbanization}

Africa's population has grown tremendously in the past decades, increasing on average by 2.53 percent annually between 1950 and $2015 .{ }^{1}$ This rapid growth is expected to continue in the next four decades. According to the latest projections, Africa's population will grow from 1.18 billion in 2015 to 2.44 billion in 2050 . Although Africa's population lives predominantly in rural areas (60 percent), the rate of rural flight to urban areas is alarming. The urbanization rate between 2000 and 2015 averaged 3.5 percent, which is the highest rate in the world. The urban share of Africa's population is expected to surpass 50 percent by $2037 .{ }^{2}$ This trend is visible in its fast-growing cities, which are also becoming more densely populated. Africa's four largest cities, with populations greater than 10 million (Cairo, Lagos, Johannesburg, and Kinshasa) account for an average of 20 percent of their countries' populations. The top 20 most populous cities account for an average of 14 percent of their countries' populations. It is important to note that there are large regional variations. Southern Africa and Northern Africa have already reached urban-majority populations, with shares of 62 percent and 52 percent, respectively. At the other end of the spectrum, Eastern and Central Africa are the least urbanized regions, with shares of 26 percent and 44 percent, respectively. Although West Africa's urban share is still below 50 percent, it is growing rapidly and is expected to surpass 50 percent in 2023. By 2050, the urban population in sub-Saharan Africa is expected to grow by almost 800 million. 
At the same time that this rapid urbanization growth is taking place, urban planning is lagging behind. In many cities, urban plans are drawn from the colonial era and are based on crude adaptations of planning polices and zoning rules existing in the United Kingdom or France in the 1940s and 1950s. Such plans are applied in a nontransparent and inconsistent manner, often to evict the poorest urban dwellers and to free land for special interests, and do not take into account the demographic, social, and economic changes that have taken place in cities over the past decades. Even new plans are often inspired by international cities in developed countries and fail to take into account local realities.

The consequence of the rapid urbanization process and inadequate urban planning are increased pressure on urban infrastructure and resources, growing housing deficits resulting in more people living in slums, urban sprawl in major agglomerations, and accelerating loss of agricultural lands.

\subsection{Housing Deficits in Africa: A Challenge for Structural Transformation}

The rapid urbanization rates and lack of urban planning have resulted in very large housing deficits, defined as the difference between the number of households and the number of permanent dwellings. The deficit can be estimated for a given period of time (flow), for example, an annual deficit, or it can be at a given date in which case it is sometimes referred to as housing backlog (stock). Without an up-to-date census of dwellings in African countries, accurate information on housing backlogs is not readily available; however, various estimates are cited by government officials and housing professionals for several countries. Following extensive research and interviews with stakeholders in several countries, we assembled the largest existing database of Africa's housing backlog, with estimates for 42 countries (Table 1.1). Although the table uses the latest information available, the estimates in some countries are a few years old. Moreover, annual shortages are often not added to the backlog; therefore, the numbers presented should be viewed as very conservative baseline estimates. 


\section{Box 1.1 Estimating the Housing Backlog and the Costs to Eliminate It}

The data in Table 1.1 was assembled following extensive literature search and conversation with housing stakeholders. For some countries, the backlog was estimated following housing profiles conducted by UN-Habitat. In other countries, the data is from past housing censuses and household surveys. Housing ministries in most countries have backlog figures they cite often but the source of those figures and the reference dates are often unknown. Therefore, the data should be viewed with caution.

The estimation of the costs to eliminate the backlog was obtained based on a few assumptions. First, we need to know what the construction costs per housing units are. As shown in Table 5.1, construction costs per square meter $\left(\mathrm{m}^{2)}\right.$ vary by housing type. The housing backlog in the continent is mostly for low- and middle-income households. Therefore, following housing typologies for this population segments in countries visited (Angola, Cameroon, Cote d'Ivoire, Ethiopia, Kenya, and South Africa), we assumed that 40 percent of the demand is for single-story detached housing unit of $40 \mathrm{~m}^{2}, 40$ percent for $60 \mathrm{~m}^{2}$ single-story apartments, and 20 percent for $80 \mathrm{~m}^{2}$ two-story apartments. Currently, most people prefer single-family, semi-detached housing, but shortage of land is making this housing option expensive and apartment living is gaining ground and will be the dominant housing typology in the future in most large African cities. The next assumption is about the growth in housing demand. Given that the demand for housing is far greater than the supply, we assumed that demand will grow with the average urbanization rate for Africa (3.5\%). These assumptions with the estimate of housing backlog and constructions costs from Table 5.1 were then used to compute the cost of eliminating the housing backlog in Africa. This estimate also needs to be viewed with caution because of the lack of accuracy of the underlying data. However, it provides a conservative estimate on how much it will cost to eliminate Africa's housing backlog.

The current housing backlog in the continent accounts for at least 51 million units, with large variation across countries. Countries such as Tunisia, Botswana, and Mauritius do not have an overall deficit as there are more dwellings than households, but deficits exist for the lowest income categories. On the other end of the spectrum, Nigeria-the most populous country, with an urbanization rate of 4.8 percent since 2000 is estimated to have a deficit of at least 17 million. This figure has been cited since 2010. However, given the annual demand of 700,000 units and annual supply of less than 100,000, the current backlog should be at 
Table 1.1 Housing backlog and urbanization in Africa

\begin{tabular}{|c|c|c|c|}
\hline Country & $\begin{array}{l}\text { Housing } \\
\text { backlog }\end{array}$ & $\begin{array}{l}\text { Urbanization rate, } \\
2000-2015^{\text {b }}\end{array}$ & $\begin{array}{l}\text { Urban share } \\
2015 \text { (percent) }\end{array}$ \\
\hline Algeria & $1,200,000$ & 2.76 & 70.7 \\
\hline Angola & $1,900,000$ & 5.34 & 44.0 \\
\hline Benin & 50,000 & 3.90 & 44.0 \\
\hline Botswana & 0 & 1.56 & 57.4 \\
\hline Burkina Faso & 100,000 & 6.33 & 29.9 \\
\hline Burundi & 30,000 & 5.75 & 12.1 \\
\hline Cabo Verde & 82,000 & 2.29 & 65.5 \\
\hline Cameroon & $1,200,000$ & 3.74 & 54.4 \\
\hline Central African Republic & $1,000,000$ & 2.26 & 40.0 \\
\hline Chad & 200,000 & 3.54 & 22.5 \\
\hline Congo & 140,000 & 3.40 & 65.4 \\
\hline Côte d'Ivoire & 600,000 & 3.31 & 54.2 \\
\hline $\begin{array}{l}\text { Democratic Republic of } \\
\text { the Congo }\end{array}$ & $3,000,000$ & 4.05 & 42.5 \\
\hline Egypt & $3,500,000$ & 1.70 & 43.1 \\
\hline Ethiopia & $1,000,000$ & 4.55 & 19.5 \\
\hline Gabon & 200,000 & 2.94 & 87.2 \\
\hline Ghana & $1,700,000$ & 3.78 & 54.0 \\
\hline Guinea & 140,000 & 3.51 & 37.2 \\
\hline Kenya & $2,000,000$ & 4.36 & 25.6 \\
\hline Liberia & 200,000 & 3.72 & 49.7 \\
\hline Libya & 350,000 & 1.52 & 78.6 \\
\hline Madagascar & $2,000,000$ & 4.60 & 35.1 \\
\hline Malawi & 100,000 & 3.55 & 16.3 \\
\hline Mali & 400,000 & 5.35 & 39.9 \\
\hline Mauritania & 50,000 & 4.03 & 59.9 \\
\hline Mauritius & 20,000 & -0.11 & 39.7 \\
\hline Morocco & 600,000 & 1.92 & 60.2 \\
\hline Mozambique & $2,000,000$ & 3.31 & 32.2 \\
\hline Namibia & 80,000 & 3.98 & 46.7 \\
\hline Niger & 100,000 & 4.72 & 18.7 \\
\hline Nigeria & $17,000,000$ & 4.78 & 47.8 \\
\hline Rwanda & 109,000 & 7.00 & 28.8 \\
\hline Senegal & 125,000 & 3.32 & 43.7 \\
\hline Sierra Leone & 166,000 & 3.58 & 39.9 \\
\hline South Africa & $2,300,000$ & 2.04 & 64.8 \\
\hline Swaziland & 20,000 & 0.85 & 21.3 \\
\hline Tanzania & $3,000,000$ & 5.19 & 31.6 \\
\hline Togo & 250,000 & 3.88 & 40.0 \\
\hline Tunisia & 0 & 1.43 & 66.8 \\
\hline
\end{tabular}


Table 1.1 (continued)

\begin{tabular}{llll}
\hline Country & $\begin{array}{l}\text { Housing } \\
\text { backlog }^{\mathrm{a}}\end{array}$ & $\begin{array}{l}\text { Urbanization rate, } \\
2000-2015^{\mathrm{b}}\end{array}$ & $\begin{array}{l}\text { Urban share } \\
2015 \text { (percent) }\end{array}$ \\
\hline Uganda & $1,600,000$ & 5.27 & 16.1 \\
Zambia & $1,500,000$ & 3.95 & 40.9 \\
Zimbabwe & $1,250,000$ & 0.96 & 32.4 \\
Africa & $50,562,000$ & 3.5 & 40.4 \\
\hline
\end{tabular}

anline sources, expert interviews

bUnited Nations Population Division, World Urbanization Prospects, 2014 revision

least 20 million. Whether 17 or 20 million, reducing the housing backlog in Nigeria requires a fundamental change in housing delivery. Three other countries have backlogs of at least 3 million housing units: the Democratic Republic of Congo (DRC), Egypt, and Tanzania. All three countries have large populations but different urbanization trends. Egypt is the most urbanized, with an urban share of 43.1 percent in 2015. Its urbanization rate for 2000-2015 was 1.7 percent, and that figure is expected to increase slightly to 1.8 percent in the next 15 years. The DRC, with an urban share of 42 percent in 2015, has experienced an urbanization rate of 4.0 percent since 2000. However, this trend is expected to slow down to an average of 3.6 percent in the next 15 years. Combined with an annual housing deficit of 240,000 units (mid-2000s estimate), the housing situation is expected to worsen. Tanzania started with a low urban share but has experienced one of the highest urbanization rates, at 5.2 percent, since 2000. Another group of countries, comprising Kenya, Madagascar, Mozambique, and South Africa, have housing backlogs of at least 2 million units. This figure is increasing annually, given the large supply shortfall and high urbanization rates.

Overall, 17 African countries have housing deficits of more than 1 million units. If nothing is done to dramatically change the situation, poor urban planning and inadequate housing supply will severely constrain Africa's structural transformation. The shortage of housing will lead to an increase in slums, which are associated with a number of social problems: overcrowding, poor sanitation, and high crime rates. Beyond the social consequences, housing shortages have economic consequences as they 
decrease labor participation in the formal sector and reduce productivity. Indeed, the economic benefits of agglomeration are realized only if people have the opportunity to fully participate in economic activities and firms can benefit from economies of scale.

\subsection{Housing Construction as an Economic Opportunity and Source of Job Creation}

The large housing backlog in Africa can be viewed as both a huge challenge and a tremendous opportunity to expand economic activity and create millions of jobs. The links between housing investments and economic development have been established for many regions at different periods of time (Chen and Zhu 2008; Terzi and Bolen 2007; Doling et al. 2013). In developed countries, the construction sector is viewed as a large contributor to economic activity and job creation. This view has led to various support measures for the housing sector that have created bubbles and are believed to be the main cause of the recent global financial crisis.

Despite losing a large share of employment and output, the construction sector continues to be important in member countries of the Organization for Economic Co-operation and Development (OECD). OECD data show that in the European Union, the sector provided 14.8 million direct jobs and contributed to 5.4 percent of GDP in 2014. In the United Kingdom, the sector employed 2.3 million people and contributed to 6.2 percent of GDP. In the United States, the sector's contribution to GDP has declined from 5.3 percent in 2006 to 3.9 percent in 2013, but it still employed nearly 10 million people in 2014. Data from the US Bureau of Economic Analysis show that residential investment and housing services accounted for 15.3 percent of US GDP in 2014. In the OECD overall, the construction sector employs 36.1 million people and contributes to 5.2 percent of GDP. The large direct effects are not limited to developed countries. In 2014, the sector accounted for 6.3 percent of GDP in Brazil, 7.9 percent in Chile, 6.9 percent in China, and 10.1 percent in Indonesia. 
In addition to direct effects, there are large multiplier effects for both jobs and economic activity. Industry associations in various countries have estimated the job and economic multipliers of housing construction. The economic multiplier for construction in Australia is estimated at 2.9, which means that $A \$ 1$ (US\$0.76) spent in construction generates a total output of A $\$ 2.9$ (US\$2.2). For every A $\$ 1$ million spent, the sector creates 37 jobs overall (9 direct, 7 indirect, and 21 induced) (ABS 2007). A 2009 study commissioned by the Canada Mortgage and Housing Corporation found that the construction of one single-family house generates Can $\$ 330,000$ (US\$254,736) in direct and indirect economic impact and creates 1.9 direct and indirect jobs with large induced effects (Altus Group Consulting 2009). In the United Kingdom, £1 (US\$1.29) spent on construction generates $£ 2.8$ (US\$3.62) in output (L.E.K Consulting 2009). It is estimated that 1.5 jobs are directly created for every new house built, with multipliers of about 2.51, meaning that one construction job leads to 1.51 indirect and induced jobs (Home Builders Federation and Nathaniel Litchfield \& Partners 2015). Overall, estimates range between 4 and 4.6 jobs per house built in the United Kingdom (Kleinman 2014). In the United States, the National Association of Home Builders (NAHB) estimates that the construction of an average single-family home creates 2.9 direct and indirect jobs and adds US $\$ 280,433$ to the economy in the form of wages and profits (Emrath 2014). It also generates US $\$ 110,957$ in tax revenues to all levels of government. When induced effects are taken into account, the construction of 100 single-family homes in a typical state leads to US $\$ 30.4$ million in income, US\$6.1 million in taxes, and 491 jobs. In addition to the impact of the new housing construction, the annual flow of housing services generates $\$ 4.6$ million in income, $\$ 1.6$ million in taxes, and 78 jobs (NAHB 2015).

The large indirect economic effects of housing construction are similar in developing countries. A literature review by Katsura (1984) shows that the economic multiplier for housing investment in Columbia, Korea, Pakistan, India, and Mexico is about 2. The labor intensity of housing varies across countries but is found to be high, with higher employment creation for low-cost housing construction. A 2014 study by the National 
Council of Applied Economic Research for India finds that construction and housing services contribute 19.6 percent of GDP, with employment in residential construction accounting for 6.9 percent of total employment. Among all sectors, labor intensity for residential construction is found to be the highest, with an employment to output ratio of 2.34, as compared with 2.11 for agriculture, the second highest ranked sector, and 0.42 on average for all sectors. Overall, the economic effect of residential construction is significantly high. One Indian rupee (US\$0.0154) spent in residential construction creates additional income of Rs 1.54 (US\$0.0237) in related industries (indirect effects) and Rs 2.84 (US\$0.0438) in overall output, considering the ripple effects of spending from income earned from the construction activity. Moreover, an investment of Rs 100,000 (US\$1543) in housing generates 2.69 direct and indirect jobs and 4.06 jobs overall, considering induced effects. The spending multiplier effect in the Philippines is much higher, as 1 peso (US\$0.0197) spent on housing activities generates 16.61 pesos (US\$0.328) in total output (Uy 2006).

Data on the impact of housing construction in Africa are scarce. However, UN-Habitat and ILO (1995) estimate that given the sector's high labor intensity, housing construction has multiplier effects on initial investment of between 2 and 3 in most developing countries. It is important to stress that the magnitude of the multiplier depends on the import content of housing construction. Viruly (2014) shows that every house built in South Africa creates 3.14 direct jobs and 2.48 indirect jobs. In Ethiopia, data from the Ministry of Urban Development, Housing, and Construction show that the government housing program generates about 2.24 direct jobs per housing unit constructed.

It is clear from the above that eliminating the housing deficit in Africa constitutes a huge economic opportunity including contribution to GDP, job creation, and tax revenues. We estimate the minimum cost to eliminate the housing backlog in 10 years at US\$2.08 trillion. Although eliminating the housing backlog represents a huge investment, doing so will also generate large economic effects. It will result in a total output of US\$5.07 trillion, using a conservative spending multiplier of 2.5. Using an estimate of four jobs overall per house built, eliminating the housing deficit will create 288 million full-time-equivalent jobs in 10 years, or 26 
million per year on average. In the bigger picture, these projections show that embarking on massive housing programs in the continent will be important in absorbing the bulge in unemployed youth and will create a solid industrial base.

Theoretically, another important channel through which housing investment affects the economy is the development of housing finance (see Chap. 3). As housing purchases require large investments, strong housing performance is associated with the development of housing finance. The links between housing finance and financial sector development are well established (Wolswijk 1993). The first impact is increased personal savings to cover initial down payments and monthly installments. Housing loans, which in general are secured by collateral, are less risky than other types of loans; therefore, they contribute to the resiliency of the financial sector. They also give financial intermediaries a relationship with consumers for the provision of other financial products (Buckley et al. 2009). In addition, the primary mortgage market is often associated with a secondary market that increases the flow of funds in the financial sector and provides additional securities. This attracts institutional investors such as pension funds and insurance companies and leads to diversification of risks (Dubel 2007).

\subsection{Housing Deficits in Africa: A Human Right and Social Development Issue}

An adequate shelter is one of the basic needs of humans, along with food and clothing. Most of the countries in Africa have one way or the other included access to a decent shelter in their Constitution. The social development aspect of housing is recognized by Goal 11 of the 2030 agenda for sustainable development: "Make cities and human settlements inclusive, safe, resilient, and sustainable." The literature has established clear links between housing conditions and social outcomes, including health, social belonging, education outcomes, social security, and satisfaction with living conditions (Doling et al. 2013; Thomson and Pettigrew 2005).

Using data from the Demographic and Health Surveys and the Mo Ibrahim Foundation, we find a clear positive correlation (0.32) in Africa, 


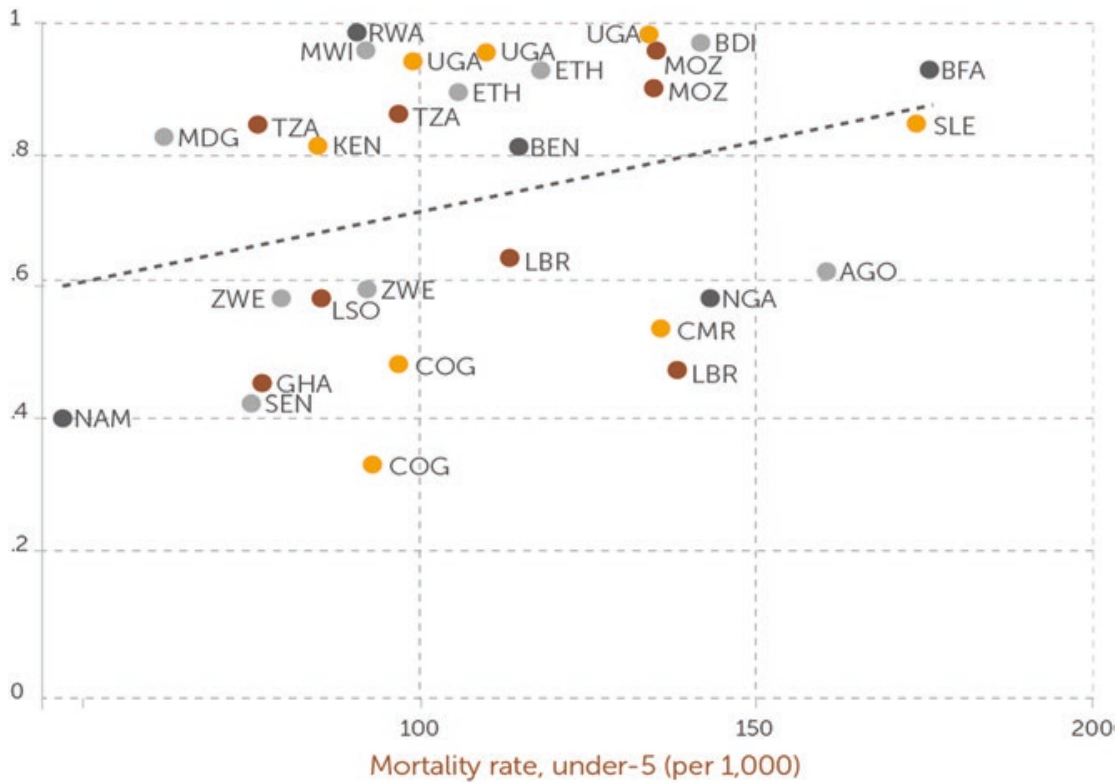

Fig. 1.1 Housing quality and child mortality (Source: Based on demographic and health survey and Mo Ibrahim Foundation data)

between the percentage of households living in poor-quality housing and the rates of child mortality (Fig. 1.1). Poor housing conditions-sanitation and ventilation — can lead to higher child mortality through higher incidences of malaria, waterborne diseases, or respiratory issues. Data from the Demographic and Health Surveys for eight of the ten African countries with the highest incidence of malaria show a clear link with poor-quality housing (Fig. 1.2).

\subsection{Africa's Housing Finance: A Challenging Environment}

The financing of housing development, like many other development issues faced by African countries, is quite challenging. This is mainly due to the lack of adequate conditions or resources to facilitate such financing. In fact, the housing finance market in Africa is exposed to a number 


\section{$\%$ of population}

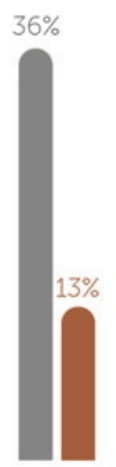

Uganda

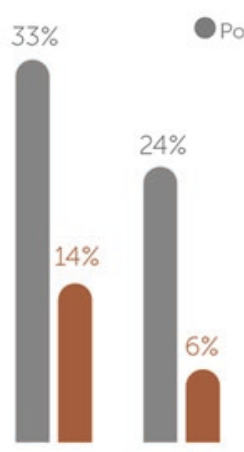

Nigeria

Burkina Faso

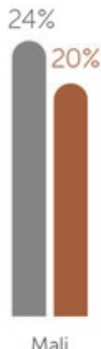

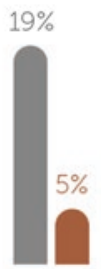

Guine
Improved toilet facility
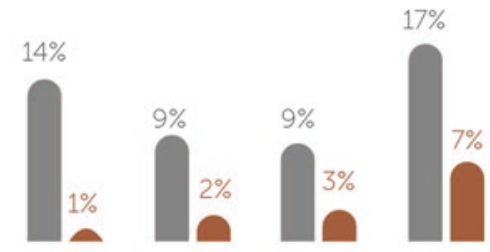

Total

Fig. 1.2 Malaria incidence by type of toilet facility (Source: Based on demographic and health survey data)

of risks. Diamond and Lea (1995) classify these risks under six categories: (1) credit risk arising from the fact that the borrowers may fail to pay back their loans; (2) liquidity risk stemming from maturity mismatch; (3) cash flow risk - which includes interest rate, prepayment, inflation, and exchange rate risks - which increases uncertainty about cash flows over time as the credit may be worth more or less over time; (4) agency risk or information asymmetry risk (moral hazard or adverse selection type of risks) that a divergence of interests will cause an intermediary to behave in a manner other than expected; (5) systemic risk, or the risk that a crisis at one institution or in a part of the system will affect the whole system; and (6) political risk, which refers to uncertainty about adverse government action that can trigger the other risks. In Africa, these risks are present in varying degrees. The management and mitigation of such risks are key elements that the finance system factors into the design and pricing of housing finance products, which ultimately affect the availability and supply of long-term capital for affordable housing. These risks are reflected by a very challenging environment characterized by weak legal frameworks and enforcement of property rights, by information asymmetry and credit risk, and by low levels of financial intermediation and a lack of long-term funding. These characteristics are examined in the following subsections. 


\subsubsection{Weak Legal Framework and Enforcement of Property Rights}

Strong protections for privately held property are a prerequisite for attracting private capital to affordable housing. In most African countries, it is difficult to "crowd in" private investment due to weak legal and regulatory frameworks, which result in high payoffs for rent-seeking behavior. The facts that property rights are not always well defined and not strongly enforced constitute high risks that scare away scarce private investments. Reportedly, in many countries, the ability to use propertyincluding land - as collateral to secure a loan is often constrained by legal uncertainties. Moreover, extensive foreclosure processes and related high costs are additional factors pushing away private investors. This is true in housing finance systems around the continent, where the principal asset at stake is land or a property sitting on that land, under a land tenure regime that is inadequate and does not promote strong property rights (see Chap. 4). This basically prevents the housing finance system from going "down market" and catering to low-income households, with which those risks are higher.

\subsubsection{Information Asymmetry and Credit Risk}

If one is concerned with allocating resources in an optimal fashion, information is key. Information asymmetry, or the lack of data-whether through moral hazard, adverse selection, or non-verifiability-could prevent society from achieving a first-best allocation of resources because of the additional costs that such asymmetry entails (Laffont and Martimort 2002). ${ }^{3}$ These constitute transaction costs, which are challenging and very difficult to manage (Akerlof 1970; Spence 1974; Williamson 1975; Rothschild and Stiglitz 1976). Without adequate incentive mechanisms, investors and financial institutions cannot effectively price and manage risks. As a result, investors may have to incur some additional transaction costs due to the information gap. This risky situation is prevalent in many African countries, where information is 
imperfect and credit history information on individuals and firms is often not available. As a result, in Africa, as in other emerging markets, commercial banks shy away from lending to households that earn low and informal income.

What is more, this aversion of credit risk by the conventional banking sector does not seem to take into account the fact that the informal sector dominates Africa's economy. In sub-Saharan Africa, according to the African Development Bank (AfDB 2013), 55 percent of the economic output derives from the informal sector and 80 percent of the labor force is employed in it. In South Africa, for instance, the size of the informal economy is estimated to be R 157 billion (US\$12.5 billion), according to the Institute of Economic Research on Innovation in South Africa. However, as a reflection of commercial banks' inexperience with putting in place the right incentive mechanisms, including underwriting processes tailored to risky clients, such banks continue to ignore this market segment while keeping lending on a tight leash. This has undoubtedly affected the development of mortgage markets in some African countries. The evidence from selected countries seems to point to an inverse relationship between the size of the informal economy and the depth of mortgage markets. In South Africa and Namibia, the countries with the most developed mortgage markets, the informal sector accounts for 33 percent and 44 percent of economic activities, respectively. Conversely, in countries where the informal economy dominates, such as Mali (82 percent), Côte d'Ivoire (78 percent), Tanzania, and Zambia (76 percent each), the mortgage market is very shallow.

\subsubsection{Credit Markets and Macroeconomic Volatility}

In many African countries, the capital markets remain shallow and are not a significant source of financing for long-term housing investments. They are dominated by bond markets (Fig. 1.3), which are highly driven by treasury bills. This reflects the share of government debt, which sometimes crowds out commercial banks, thus limiting the availability of adequate funding instruments. In addition, the contractual savings industry 


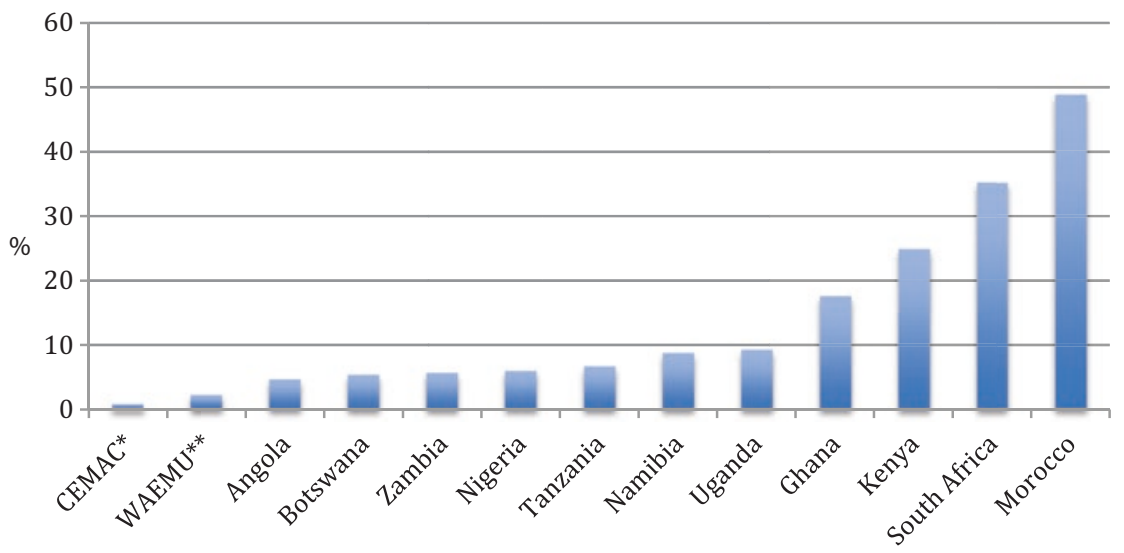

Fig. 1.3 African bond market size, as a percentage of GDP (Sources: African Market Initiative; *CONSUMAF (cumulative issues 2007-2001); **CREPMEF (market capitalization))

(insurance companies, pension funds, etc.) is not sufficiently developed. As such, this source of long-term institutional capital remains untapped. Furthermore, the few existing financial instruments are inadequate to address the long-term housing financing need.

Consequently, most housing loans in the continent are funded through short-term deposits. This can be done up to a certain extent, depending on the stability of deposits, the existence of deposit guarantee schemes, or the degree of political and social stability. These conditions do not always exist, and in the majority of countries, the lack of long-term financing is a significant roadblock to the development of housing finance. In some countries, such as those that are members of the West Africa Economic and Monetary Union (WAEMU) and the Central African Economic and Monetary Community (CEMAC), for instance, term transformation regulations that link long-term assets to long-term resources further constrain the provision of medium- and long-term credit for housing. This phenomenon translates to short loan tenors, which increases the costs of mortgages, thereby pricing out many potential borrowers as the repayment period is spread over a shorter time period. 


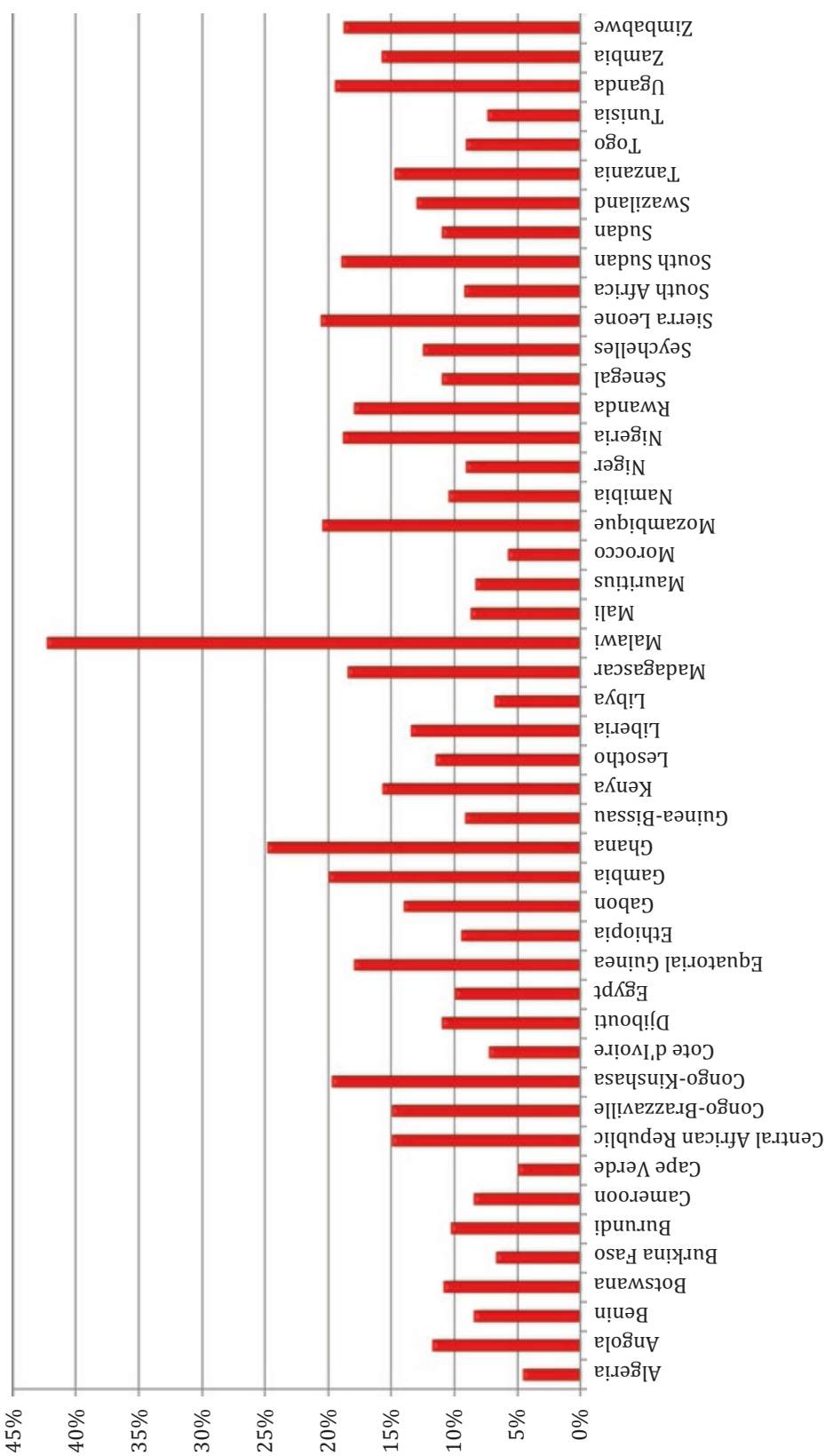


Besides, in many African countries, the level of financial intermediation is reported to still be low, with the ratio of credit to the economy over GDP barely reaching 18 percent, implying limited involvement of the financial system in financing the economy. This is a reflection of the inadequate financing instruments and the weak finance markets, as explained above. Macroeconomic stability is a key feature for the development of the housing finance system and requires sound management of inflation and interest rates to avoid economic volatility. Unfortunately, both high inflation rates and rising interest rates are widespread in many African countries, which inherently affect housing affordability. Doubledigit interest rates on residential mortgages and housing loans are the norm in many countries, with a few exceptions in countries such as Morocco, Tunisia, and South Africa. These high lending rates are often associated with high inflation and currency depreciation, which reflect to some extent the low development of the housing finance system on the continent. Figure 1.4 captures average interest rates for mortgages in selected countries. In many countries, interest rates are variable, with Morocco being the only exception as mortgage interest rates are fixed.

High inflation and interest rates have continuously plagued mortgage lending in both developed and developing economies. Primary mortgage lenders in Kenya, Nigeria, Tanzania, and many other countries identify high interest rates as the principal obstacle to mortgage market development efforts. In the absence of generally accepted interest rate benchmarks, rate changes are based on the internal cost of funds, a nontransparent approach that nonetheless allows for the smoothing out of ample fluctuations - to the point that loans are commonly perceived as being fixed rate (e.g., in WAEMU and CEMAC countries).

\section{Notes}

1. UN Population Division, World Population Prospects, 2015 revision.

2. UN Population Division, World Urbanization Prospects, 2014 revision.

3. For details on the asymmetry of information problem, see Akerlof (1970), Spence (1974), Williamson (1975), Rothschild and Stiglitz (1976), or Laffont and Martimort (2002). 


\section{Bibliography}

ABS (Australian Bureau of Statistics). 2007. The Construction Industry's Linkages with the Economy. Belconnen, Australian Capital Territory. http://www.abs. gov.au/Ausstats/abs@.nsf/94713ad445ff1425ca25682000192af2/ed622007 2793785eca256b360003228f!OpenDocument.

AfDB (African Development Bank). 2013. Recognizing Africa's Informal Sector. Abidjan. http://www.afdb.org/en/blogs/afdb-championing-inclusive-growthacross-africa/post/recognizing-africas-informal-sector-11645/.

Akerlof, G. 1970. The Market for 'Lemons': Quality Uncertainty and the Market Mechanism. Quarterly Journal of Economics 84: 488-500.

Altus Group Economic Consulting. 2009. Economic Impacts of Residential Construction. Report for the Canada Mortgage and Housing Corporation, Ottawa. http://www2.hamilton.ca/NR/rdonlyres/1F84E3C3-009A-46AFB95E-7F6D3F05D697/0/Jun17Item88iieconomicimpact.pdf.

Ball, Michael. 2015. The Labor Needs of Extra Housing Output: Can the Housebuilding Industry Cope, Report for the Home Builders Federation, London. http://www. hbf.co.uk/?eID=dam_frontend_push\&docID=20266\&filename=CITB_ REPORT.pdf.

Buckley, R., L. Chiquier, and M. Lea. 2009. Housing Finance and the Economy. In Housing Finance Policy in Emerging Markets, ed. L. Chiquier and M. Lea. Washington, DC: World Bank.

Chen, Jie, and Aiyong Zhu. 2008. The Relationship Between Housing Investment and Economic Growth in China: A Panel Analysis Using Quarterly Provincial Data, Uppsala University Working Paper, Sweden. http://www.diva-portal. org/smash/get/diva2:128349/FULLTEXT01.pdf.

Diamond, D., and M. Lea. 1995. Sustainable Financing for Housing: A Contribution to Habitat II. Fannie Mae, Office of Housing Research Working Paper, Washington, DC.

Doling, John, Paul Vandenberg, and Jade Tolentino. 2013. Housing and Housing Finance-A Review of the Links to Economic Development and Poverty Reduction, ADB Economics Working Paper Series No. 362. Asian Development Bank, Manila. http://www.adb.org/publications/housing-andhousing-finance-review-links-economic-development-and-poverty-reduction.

Dubel, H. 2007. Does Housing Finance Promote Economic and Social Development in Emerging Markets? Study commissioned by the International Finance Corporation, Washington, DC. http://www.hofinet.org/documents/doc. aspx?id=260. 
Emrath, Paul. 2014. Impact of Home Building and Remodeling on the U.S. Economy, Report for the National Association of Home Builders, Washington, DC. https:/www.nahb.org/en/research/housing-economics/ housings-economic-impact/impact-of-home-building-and-remodeling-onthe-u-s--economy.aspx.

Home Builders Federation and Nathaniel Litchfield \& Partners. 2015. The Economic Footprint of UK House Building. London. http://www.hbf.co. $\mathrm{uk} /$ ?eID=dam_frontend_push $\&$ docID $=24568 \&$ filename=Economic_ Fotprint_BPF_Report_March_2015_WEB_01.pdf.

Katsura, Harold M. 1984. Economic Effects of Housing Investment, Report for USAID Office of Housing and Urban Programs, Washington, DC. http:// pdf.usaid.gov/pdf_docs/PNAAU426.pdf.

Kleinman, Mark. 2014. Measuring Jobs from the Housing Programme, Appendix 3 of Progress Report. London City Government. https://www.london.gov.uk/ moderngov/documents/s38594/Measuring\%20Jobs_Appendix\%203.pdf.

L.E.K Consulting. 2009. Construction in the U.K Economy-The Benefits of Investment, Summary of a report commissioned by the UK Contractors Group, London. http://www.wates.co.uk/sites/all/modules/filemanager/files/ PDF/L.E.K._Construction_in_the_UK_Economy.pdf.

Laffont, J.-J., and D. Martimort. 2002. The Theory of Incentives: The PrincipalAgent Model. Princeton: Princeton University Press.

NAHB (National Association of Home Builders). 2015. The Economic Impact of Home Building in a Typical State: Income, Jobs, and Taxes Generated. Washington, DC. https://www.nahb.org/ //media/Sites/NAHB/Economic\%20studies/1REPORT_local_20150318115955.ashx?la=en.

National Council of Applied Economic Research. 2014. Impact of Investments in the Housing Sector on GDP and Employment in the Indian Economy. New Delhi. http://mhupa.gov.in/writereaddata/UploadFile/Impact_of_Housing on_GDP_Employment_FULL_REPORT.pdf.

Rothschild, M., and J. Stiglitz. 1976. Equilibrium in Competitive Insurance Markets. Quarterly Journal of Economics 93: 541-562.

Spence, M. 1974. Market Signaling: Informational Transfer in Hiring and Related Processes. Cambridge, MA: Harvard University Press.

Terzi, Fatiha, and Fulin Bolen. 2007. The Impacts of Housing on Economic Development, Presented at the 14th Annual European Real Estate Society Conference, London, June 27-30.

Thomson, H., and M. Pettigrew. 2005. Is Housing Improvement a Potential Health Improvement Strategy? Health Evidence Network Report, World Health Organization Regional Office for Europe, Copenhagen. 
UN-Habitat and ILO. 1995. Shelter Provision and Employment Generation. United Nations Human Settlements Programme and International Labor Organization, Nairobi and Geneva.

Uy, Willie J. 2006. Medium-Rise Housing: The Philippines Experience, Presentation at the 5th Asian Forum, Tokyo, Japan.

Viruly, Francois. 2014. What Are the Derived Social Benefits of Occupying Affordable Housing in South Africa? A Social Audit Conducted on Residential Units Built by International Housing Solutions, Study commissioned by International Housing Solutions, Gauteng, South Africa. http://www.ihsinvestments.co.za/ wp-content/uploads/2015/07/2012_IHS-Final-Report-1.pdf.

Williamson, O. 1975. Markets and Hierarchies. New York: The Free Press.

Wolswijk, Guido. 1993. Housing: Enabling Markets to Work. Washington, DC: World Bank.

Open Access This chapter is licensed under the terms of the Creative Commons Attribution 4.0 International License (http://creativecommons.org/ licenses/by/4.0/), which permits use, sharing, adaptation, distribution and reproduction in any medium or format, as long as you give appropriate credit to the original author(s) and the source, provide a link to the Creative Commons license and indicate if changes were made.

The images or other third party material in this chapter are included in the chapter's Creative Commons license, unless indicated otherwise in a credit line to the material. If material is not included in the chapter's Creative Commons license and your intended use is not permitted by statutory regulation or exceeds the permitted use, you will need to obtain permission directly from the copyright holder.

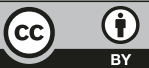

